Such is the progress of the century. Since the discovery of the first enzyme we have travelled far to form a conception of an enzyme as an active spot of specific configuration at part of the surface of the colloid particle. Progress has been slow, largely because chemists and biologists have not been ready for such a conception and all that its application involves. Now at the beginning of the second century of enzyme study, things are different; the authoritative summary by the president of the Royal Society in closing the old period serves to open the new at a moment when the army of research workers is ready to apply it.

\title{
Obituary
}

\section{Prof. C. Correns}

THE death on February 15 of Prof. Carl Correns at the age of sixty-eight years leaves a gap in the ranks of those who were prominent in the Mendelian investigations from their inception in 1900. Much of his work was in the more obscure and difficult fields of plant genetics, such as self-sterility, variegation and the inheritance of sex. He brought a wide knowledge of plants and a broad biological outlook to bear on these and other problems, and will always be held in remembrance as one of the three co-discoverers of Mendel's principle of segregation in hybrids.

When Hugo de Vries published his paper "Sur la loi de disjunction des hybrides" in the Comptes rendus of the Paris Academy of Sciences in March 1900 , announcing the re-discovery of Mendelism, based on the study of eleven different species, Correns was stimulated to write immediately, as he says, a paper for the Berichte der deutschen botanischen Gesellschaft, which was entitled "G. Mendel's Regel über das Verhalten der Nachkommenschaft der Rassenbastarde", in which he showed how he had independently arrived at the same conclusions as de Vries through experiments with maize and peas. $\mathrm{He}$, like de Vries, at first thought his resuits and conclusions were new, and then found Mendel's paper of 1866 with similar results and the same explanation of them, namely, the principle of genetic segregation. In the previous year he had published an explanation of the phenomena of xenia in maize and in 1901 he wrote another extensive and classical paper on this subject.

Correns was thus a leading spirit in the rediscovery of Mendel's laws and in a clear statement of the mode of sex determinations in diœecious and polygamous flowering plants. Important investigations on the latter subject were published in 1907, in which the Mendelian conceptions were applied to the inheritance and determination of sex in plants. This was the period when active discoveries of the sex chromosomes in insects were taking place, and in 1913 he published in collaboration with Goldschmidt a general work on what we would now call the genetics of sex. Several other investigations of sex in plants appeared during the next decade, Melandrium, Silene and Rumex being among the forms mainly studied.

Many of Correns's researches were fundamental and he preferred to labour in fields that were off the beaten track. The number of plant genera with which he worked at different periods was a surprisingly large one. In a series of papers on Mirabilis hybrids, beginning in 1902, he showed that when the yellow and white varieties are crossed, the $F_{1}$ is rose-coloured with red stripes while the $F_{2}$ produces no less than eleven colour types. This was important at a time when it seemed that Mendel's law of dominance might be as fundamental as his law of segregation. The influence on the offspring of the number of pollen grains placed on the stigma was also investigated in Mirabilis, and several interspecific hybrids of Matthiola incana, M. glabra and other species were analysed. Other genera the genetics of which he studied included Urtica, Trinia, Hyoscyamus, Dimorphotheca, Lamium, Veronica (long and short style), Linum and Fagopyrum.

Correns was interested in the rôle of the cytoplasm in inheritance and published an important paper on this subject in 1909 . He studied variegation and its inheritance, finding cases where the development of the chloroplasts was under nuclear control and therefore Mendelian in inheritance, while in other cases the control was cytoplasmic. His paper at the Berlin Congress of Genetics in 1927, of which he was a vice-president, was a masterly summary of knowledge regarding nonMendelian inheritance in plants and animals, but he was prevented by illness from giving it in person.

So early as 1889 , Correns made a study of pollen germination and the pollen tubes of Primula acaulis, and much later he showed in Melandrium, by placing a few pollen grains on the stigma, that the upper ovules of the flower are generally fertilised first.

Darwin's experiments on self-sterility led him to the view that in such cases each plant, although self-sterile, can be fertilised by pollen from any other plant. This hypothesis of individual stuffs was held until the work of Correns on Cardamine pratensis in 1912, in which he found that the offspring of two crossed plants fell into four interfertile groups, and the inheritance of self-sterility could be explained on a Mendelian basis. This conception has since been confirmed and extended in other genera. In 1928, however, Correns found that in Tolmiea Menziesii the individuals from a cross were fully fertile with each other, as Darwin had supposed, and it is possible that in this species the determination of the stuffs inhibiting pollen tube growth is not genotypic but phenotypic. 
Correns was born in Munich on September 19, 1864, his father being a painter and a member of the Bavarian Academy of Art. In 1892 he went to Tübingen and in 1899 was made an extraordinary professor in that University. He went from there to Leipzig in 1902, and in 1909 became professor of botany at Münster in Westphalia. It was there that I first met him, in 1910. An animated discussion with him in the streets of Münster, surrounded by curious onlookers, made one feel rather like one of the disputants in a university town in the Middle Ages. With his bright red hair, thick glasses and large hands with extremely long nails trimmed to a point, he was a man of extraordinary appearance in his younger days. When the Kaiser Wilhelm Institute for Biological Research was founded at Berlin in 1914 he was called to be its first director and was also made an honorary professor in the University of Berlin. $\mathrm{His}$ connexion with this research institute was maintained to the end, its extensive garden, greenhouses and laboratories being the scene of all his later work. An early work, published in 1899, had to do with vegetative multiplication in the mosses, but nearly all his later investigations had some bearing on genetics.

In 1924, on the occasion of his sixtieth birthday,
Correns's collected works on plant genetics, numbering sixty papers, were published in a volume of some 1,300 pages. He married a niece of Nägeli and published (1905) Mendel's letters to Nägeli, in which an unsuccessful attempt was made by Mendel to interest Nägeli in his views regarding the phenomena of heredity. They were republished as an appendix to the volume of collected works.

Correns may be said to occupy a somewhat similar place in modern plant genetics to that of Kölreuter in the eighteenth century. His results were always clearly and methodically presented. $\mathrm{He}$ held several honorary degrees, was a member of the Prussian Academy of Sciences, and in 1931 was elected a foreign member of the Linnean Society of London.

R. Ruggles Gates.

WE regret to announce the following deaths:

Prof. C. W. Cook, professor of economic geology in the University of Michigan, known for his work on oil geology, on February 17, aged fifty years.

Prof. Erik G. Odelstierna, professor of the metallurgy of iron in the Technical High School, Stockholm, from 1904 until 1918, aged seventynine years.

\section{News and Views}

\section{Education and Economic Recovery}

IN his chancellor's address to the University of New Zealand, Dr. J. Macmillan Brown emphasised the contribution of education to recovery from the periodic economic and financial depressions in the assistance it gives to the growing mind to understand the methods and efforts of the past. Youth must be trained to know the data of the situation before it is stirred to investigate and learn the full terms of the problem before attempting its solution. Accordingly, education, and especially advanced education, should be the last element in a civilised community to be submitted to the axe of economy in meeting the want and suffering associated with a depression, and the pruning of educational resources in New Zealand and elsewhere is a definite setback to recovery. The two essentials in the recovery of a community from depression are the broadening and deepening of the intelligence of the mass so as to enable them to leam the lesson of thrift and foresight, and highly developed leaders capable of seeing far into the darkness of the future and leating their fellows to the highest practical goal. The selection and training of the intellectual leaders is the more important for advance in research, and a large proportion of exceptional material is left uncleveloped in the absence of scholarships to select and carry it through its course.

IT is the true function of a university, Dr. Macmillan Brown sidid, to select the research workers and leaders of thought who will save mankind from these recurrent dilemmas. Universities and institutions which prepare for them are the main means by which the methods of one generation are stored up and improved for the benefit of subsequent generations. Dr. Macmillan Brown pointed out that more and more widely is it being realised that selfisolation of the individual, the caste, the community, and the nation is suicidal and destructive of progress, and he urged that the transmission of advance from one community and one generation to others can only be effective, beyond such institutions as the British Commonwealth of Nations and the League of Nations, if there is fellowship and effective international co-operation between the universities. With the universities and their graduates forming the constituencies in every nation and community, mankind might make some approach to a world parliament or at least to a conference which would he competent to indicate sanely the conditions that should belong to a federation of the world. Dr. Macmillan Brown concluded his plea for the place of a trained intelligence in the direction of the affairs of mankind by pointing out that university education must be built on broader foundations than narrow specialisation and be capable of selecting the wisest, most developed minds and characters the community can produce.

\section{Roman Richborough}

AfTer eleven years excavation on the site of Roman Richborough, it is at last possible, according to the account of the most recent discovered given by 